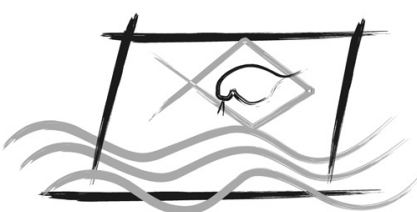

ECOTOX - BRASIL

\title{
Ecotoxicological assessment of irrigation water for vegetables in a watershed region of Greater São Paulo
}

\author{
P.M.M. LACERdA ${ }^{1}$; A.M. AsAnO ${ }^{2}$; A. Morita ${ }^{2}$; P.J. BALSAMO 2 ; \\ R. NAscimento ${ }^{2}$; E.P. TeixeirA ${ }^{1,2} \&$ S.P. Irazusta ${ }^{1,2}$ \\ ${ }^{1}$ Programa de Pós-Graduação do Centro Estadual de Educação Tecnológica Paula Souza CEETEPS \\ ${ }^{2}$ Laboratório de Ecotoxicologia, Faculdade de Tecnologia de Sorocaba-FATEC-SO
}

(Received May 08, 2013; Accept February 24 2014)

\begin{abstract}
The aim of the present study was to evaluate the quality of irrigation water for vegetables in a Greater São Paulo watershed region. Acute and chronic ecotoxicity bioassays with Dugesia tigrina and Selenastrum capricornutum and geno/mutagenicity assays with Allium cepa were performed, as well as microbiological assays for total and thermotolerant coliforms, according to the legislation. The ecotoxicological data did not show significant toxicity in any of the samples. However, surface water genotoxic effect was detected in 2 out of the 3 points and mutagenic effect in all three sampled points, as well as in the sediment, in the Allium cepa test. Such high prevalence of total and thermotolerant coliforms in all samples at the three points indicates a compromised environmental integrity of the basin due to high loads of organic pollution, probably of clandestine origin. No emissions of industrial origin were detected in the region. Thus, taken together, the results suggest that agricultural activity itself may account for the impacts in these water bodies. The present study represents a contribution to the scarce data available in the literature about this important Greater São Paulo region.
\end{abstract}

Keywords: bioassays; green belt; irrigation water; vegetables.

\section{INTRODUCTION}

Vegetables are an integral part of the world population's diet. Health concerns and the knowledge that many species are excellent sources of vitamins, minerals, and antioxidant and hypocaloric substances have led to a growing demand for green leafy vegetables over the last ten years (Taban \& Halkman, 2011).

Despite multiple health benefits provided by these plants, several studies conducted in various countries around the world, including Brazil, singled out vegetables as vehicles for spreading several diseases, a fact that is assigned mostly to the use of contaminated irrigation water (Mattos, 2003; Franco et al., 2006; Mazari-Hiriart et al., 2008; Taban \& Halkman, 2011). Almost all surface water in the greenbelts of large urban centers is severely contaminated by untreated municipal wastewater and, in spite of the risk of transmission of a number of diseases, this contaminated water has been used indiscriminately in irrigation (Marouelli \& Silva, 1998).

Freshwater reservoirs can be affected by several hazardous substances through agricultural inputs, sewage discharges, leaching and runoff (Palma et al., 2010).

Public health risks arising from the use of waste water are related to the presence of potentially pathogenic microorganisms, as well as the presence of toxic chemicals of organic and inorganic origin that above certain concentrations can be harmful both to humans and to the ecosystems (Chiou, 2008; Papadopoulos et al., 2009).

A simple physical, chemical and biological characterization is not sufficient to control the sources of water pollution. Toxicity assays should be viewed as indispensable analysis tools to control water pollution, as they detect the effects of pollutants on the biota, whereas chemical analyses only 
identify and quantify the substances present in environmental samples (Zagatto \& Bertoletti, 2006).

Water quality assessment is crucial in the implementation of monitoring programs to minimize the risk posed by dangerous substances both to the safe consumption of fruits and vegetables and to aquatic ecosystems. Assessments of the extent of contamination of aquatic environments must not take into account only their chemical characterization, but be supplemented with biological assays to evaluate potential toxic effects and allow an integrated evaluation of their impacts on the populations and communities of aquatic ecosystems. This approach has clear advantages, as it allows an overall assessment of the effects of all water components, including those that are caused by unknown and synergic substances as well as antagonistic or additive effects (Palma et al., 2010). Furthermore, such tests are important in the assessment of the so-called emerging contaminants (Yoshihara \& Murugananthan, 2009).

Several authors point to planarians as models for the evaluation of environmental contaminants, being very useful for these studies because they allow the assessment of effects at different levels of biological organization, such as molecular, cellular, physiological, or behavioral (Best \& Morita, 1991; Calevro et al., 1998; Guecheva et al., 2003).

Other studies conducted with algae showed that they have a quick physiological response, allowing the damaging effects caused by toxic compounds to be detected in a short period of time (Sicko-Goad \& Stoermer, 1988). Algae can be used as biological monitors of water quality and as indicator species to assess the environmental impact of pollutants (Hellawell, 1986).

Test systems with higher plants, such as Allium cepa, are used to study the effects of various environmental samples in order to detect genotoxicity (Teixeira et al., 2003; Fachinetto et al., 2007; Leme \& Marin-Morales, 2008). El-Shahaby et al., (2003) viewed the Allium cepa test system as the most adequate to detect toxicity and genotoxicity in order to evaluate environmental pollution levels that pose a direct or indirect risk to the human population.

This paper proposes to assess the quality of irrigation water and the potential risk of vegetable consumption in a watershed area of Greater São Paulo through the application of bioassays with sensitive organisms.

\section{MATERIAL AND METHODS}

The sampling points for this study were small watercourses located in a sub-basin of High Tietê, Cotia-Guarapiranga, which corresponds to a watershed area with many springs and watercourses, being the Embu-Mirim river a major tributary of the Guarapiranga Reservoir.

From April to September 2011, water and sediment samples were collected (in triplicate) at three points (small watercourses) used for irrigation of leafy vegetables inside private agricultural properties. There were conducted three sampling campaigns, which were held in the months of April,
June and September, with an interval of about two months between collections.

To provide a more complete evaluation, in addition to the ecotoxicological tests, physical, chemical and microbiological assays were also performed.

The methodology used to evaluate the physical and chemical properties is described in Standart Methods For The Examination of Water and Wastewater. The water quality variables were analyzed according to the quality standards established by CONAMA Resolution 357: 2005 (BRAZIL, 2005), for Class 1 waters, which are intended for irrigation of vegetables eaten raw.

The microbiological avaliation was performed according to technical standard of Enviromental Company of the State of São Paulo, for qualitative analyse of total and thermotolerant coliforms. The quantitative analyse was also performed by the serial dilutions method, according to the CETESB L5.240 Apr/91 protocol.

Three different test organisms were used in the bioassays: Dugesia tigrina (planarian), Selenastrum capricornutum (green microalga) and Allium cepa (onion). Ecotoxicity tests with planarians consisted in exposing these organisms to samples of irrigation water, both pure $(100 \%)$ and in dilutions (in distilled water) of $10 \%, 25 \%, 50 \%$ and $75 \%$, using mineral water as control. Observations were made after 48 hours (acute analysis) and 72 hours (chronic analysis) to examine aspects such as color, response to light, mobility and mortality.

With the Selenastrum capricornutum alga, chronic toxicity was evaluated by exposing it to the same sample dilutions over a 72-hour period. The toxic effect observed was the inhibition of algal biomass growth (Radix et al., 2000; USEPA, 2002; Rubinger, 2009), with cell count performed by the Neubauer chamber method.

The Allium cepa geno/mutagenicity assay was performed according to the protocol proposed by Ma et al., (1995), with modifications. For this test, first the germination of bulbs and root exposure to samples of surface water and elutriate (both pure and in dilutions of $25 \%$ and $50 \%$ in distilled water), together with controls, were performed for 24 hours, followed by a recovery period ( 24 hours). Then the roots were collected and fixated in Carnoy's solution (ethanol: acetic acid 3:1).

The slides were prepared by root hydrolysis in $\mathrm{HCl} 1 \mathrm{~N}$ for 15 minutes at $60^{\circ} \mathrm{C}$, cells were staining with Schiff base. The meristematic region and the F1 region of the root were fitted and squashed between the slide and the coverslip with a drop of carmine dye. The reading (counting of chromosomal aberrations and micronuclei) of the slides was made with optical microscope at 400x magnification. Five hundred (500) cells were counted per slide, and 3 slides were counted per treatment.

\section{Results}

\section{Physico-chemical Avalyses}

Regarding the results of physico-chemical analyses (Table 1) the values are not displayed in accordance with the national 
Table 1 - Results of analyzes of physical and chemical parameters

\begin{tabular}{|c|c|c|c|c|c|c|c|c|c|c|}
\hline \multirow{3}{*}{ Parameters } & \multirow{3}{*}{ Reference Values } & \multicolumn{3}{|c|}{ Campaign 1} & \multicolumn{3}{|c|}{ Campaign 2} & \multicolumn{3}{|c|}{ Campaign 3} \\
\hline & & \multicolumn{9}{|c|}{ Sampling Points } \\
\hline & & 1 & 2 & 3 & 1 & 2 & 3 & 1 & 2 & 3 \\
\hline $\begin{array}{l}\text { Ambient } \\
\text { Temperature }\left({ }^{\circ} \mathrm{C}\right)\end{array}$ & ---- & 17 & 17 & 17 & 17 & 18 & 18 & 16 & 15 & 17 \\
\hline $\begin{array}{l}\text { Water Temperature } \\
\left({ }^{\circ} \mathrm{C}\right)\end{array}$ & ---- & 17 & 16 & 17 & 12 & 13 & 13 & 13 & 13 & 13 \\
\hline $\mathrm{pH}$ & $6,0-9,0$ & 6,4 & 6,5 & 6,6 & 6,2 & 6,3 & 6,3 & 6,6 & 6,9 & 6,8 \\
\hline $\begin{array}{l}\text { Dissolved oxygen - } \\
\mathrm{OD}\left(\mathrm{m} \mathrm{L} \mathrm{L}^{-1}\right)\end{array}$ & Mín. $6 \mathrm{mg} \mathrm{L}^{-1}$ & 5,70 & 6,11 & 6,60 & 5,21 & 5,41 & 5,80 & 4,07 & 4,57 & 4,32 \\
\hline Iron $\left(\mathrm{mg} \mathrm{L}^{-1}\right)$ & Máx. $0,3 \mathrm{mg} \mathrm{L}^{-1}$ & 0,72 & 0,08 & 0,56 & $\mathbf{0 , 8 7}$ & 0,35 & 0,09 & 2,80 & 1,52 & 2,94 \\
\hline $\begin{array}{l}\text { Conductivity }(\mu \mathrm{S} \\
\left.\mathrm{cm}^{-1}\right)\end{array}$ & Máx. $100 \mu \mathrm{S} \mathrm{cm}^{-1}$ & 428 & 177 & 204 & 370 & 220 & 250 & 339 & 170 & 205 \\
\hline Turbidity (UNT) & Máx. 40 UNT & 7,68 & 11,46 & 18,54 & 10,7 & 5,04 & 5,27 & 12,16 & 8,88 & 8,50 \\
\hline Color $\left(\mathrm{mgPt} \mathrm{L}^{-1}\right)$ & Máx. $75 \mathrm{mg} \mathrm{Pt} \mathrm{L-1}$ & 61 & 69 & 68 & 116 & 56 & 50 & 121 & 77 & 386 \\
\hline
\end{tabular}

* Values in bold represent values outside the standard.

legislation (CONAMA 357: 2005) determines for water irrigation of vegetables eaten raw. Important physicochemical parameters, such as dissolved oxygen, conductivity, and iron, most of the samples showed values outside the recommended for irrigation.

\section{Microbiological Avaliation}

The qualitative tests were positive for total and thermotolerant coliforms in all samples. Regarding the results of the quantitative analysis for thermotolerant coliforms (Table 2 ), it should be stressed that the number found exceeded the limits proposed both by the national legislation (BRAZIL, 2005) and the World Health Organization (WHO, 1989).

\section{Bioassay with Dugesia tigrina}

In relation to planarians (Table $3 a$ and $3 b$ ), our results showed negative responses for mortality in the three sampling series for the three spots, i.e. exposure to vegetable irrigation water was negative for acute toxicity. There was no change in color or mobility of planarians; however, a behavioral change was observed in the first and third sampling series, at all concentrations, in which the response to light was abolished, i.e. the organisms did not respond negatively to light. Such result indicates that in these two series (at all concentrations), there was a chronic toxic action on the planarians.

\section{Bioassay with Selenastrum capricornutum (Pseudokirschineriella subcaptata)}

Figure 1 shows the average results of chronic toxicity tests with Selenastrum capricornutum algae. None of the samples from all three points differed significantly from the controls in this test, which shows that there was no toxicity at all dilutions tested and therefore no inhibition of algal growth, except for the $25 \%$ dilution, in wich was observed a larger growth than that observed for the controls.
Table 2 - Number of thermotolerant coliforms in the samples

\begin{tabular}{lc}
\hline Sampling points & Thermotolerant coliforms $\left(\boldsymbol{U} \boldsymbol{F} \boldsymbol{C} \boldsymbol{m L}^{-1}\right)$ \\
\hline P1 & $>1000$ \\
\hline P2 & $>1000$ \\
\hline P3 & $>1000$ \\
\hline
\end{tabular}

\section{Bioassay with Allium cepa}

The roots of Allium cepa exposed to sediment samples collected in the three points studied, exhibited high frequencies of chromosomal aberrations (CA). The rate of chromosomal aberrations (IAC) of the samples in the three campaigns was statistically different from the negative control performed with distilled water $(\mathrm{P}<0.05$, Figure 2$)$. Regarding mutagenic activity, represented by counting micronuclei (MN) in the F1 region was also observed activity significantly different from the negative control, but only in samples from points 1 and 3, this effect was not observed in the point 2.

The same results as the IAC were also found for the bioassays performed with surface water (irrigation water). The percentage of $\mathrm{AC}$ in the samples in the three campaigns was statistically different from the negative control $(\mathrm{p}<$ 0.05 , Figure 3 ). Regarding mutagenic activity, there were no significant differences between these results and the negative control, demonstrating therefore that no mutagenicity in these samples. These results indicate that CA occurred in meristematic cells underwent repair process during cell division in the irrigation water.

\section{DISCUSSION}

Very few publications deal with the problem of chemical and/ or biological contamination of irrigation water in the state of São Paulo. A survey of the literature in the last 20 years, particularly concerning the metropolitan region of São Paulo (MRSP), shows 
Table 3a - Acute toxicity tests with planarians (Dugesia tigrina) - Mortality of individuals after $48 \mathrm{~h}$

\begin{tabular}{|c|c|c|c|c|c|c|c|c|c|c|c|c|c|c|c|c|c|c|}
\hline \multirow[b]{2}{*}{ Samples } & \multicolumn{3}{|c|}{$10 \%$} & \multicolumn{3}{|c|}{$25 \%$} & \multicolumn{3}{|c|}{$50 \%$} & \multicolumn{3}{|c|}{$75 \%$} & \multicolumn{3}{|c|}{$100 \%$} & \multicolumn{3}{|c|}{ Control } \\
\hline & 1 & 2 & 3 & 1 & 2 & 3 & 1 & 2 & 3 & 1 & 2 & 3 & 1 & 2 & 3 & 1 & 2 & 3 \\
\hline $\mathrm{P} 1$ & $0 / 5$ & $0 / 5$ & $0 / 5$ & $0 / 5$ & $0 / 5$ & $0 / 5$ & $0 / 5$ & $0 / 5$ & $0 / 5$ & $0 / 5$ & $0 / 5$ & $0 / 5$ & $0 / 5$ & $0 / 5$ & $0 / 5$ & $0 / 5$ & $0 / 5$ & $0 / 5$ \\
\hline P2 & $0 / 5$ & $0 / 5$ & $0 / 5$ & $0 / 5$ & $0 / 5$ & $0 / 5$ & $0 / 5$ & $0 / 5$ & $0 / 5$ & $0 / 5$ & $0 / 5$ & $0 / 5$ & $0 / 5$ & $0 / 5$ & $0 / 5$ & $0 / 5$ & $0 / 5$ & $0 / 5$ \\
\hline P3 & $0 / 5$ & $0 / 5$ & $0 / 5$ & $0 / 5$ & $0 / 5$ & $0 / 5$ & $0 / 5$ & $0 / 5$ & $0 / 5$ & $0 / 5$ & $0 / 5$ & $0 / 5$ & $0 / 5$ & $0 / 5$ & $0 / 5$ & $0 / 5$ & $0 / 5$ & $0 / 5$ \\
\hline
\end{tabular}

Table 3b - Chronic toxicity tests with planarians (Dugesia tigrina)

\begin{tabular}{|c|c|c|c|c|c|c|c|c|c|c|c|c|c|c|c|c|c|c|}
\hline \multirow[b]{2}{*}{ Samples } & \multicolumn{3}{|c|}{$10 \%$} & \multicolumn{3}{|c|}{$25 \%$} & \multicolumn{3}{|c|}{$50 \%$} & \multicolumn{3}{|c|}{$75 \%$} & \multicolumn{3}{|c|}{$100 \%$} & \multicolumn{3}{|c|}{ Control } \\
\hline & 1 & 2 & 3 & 1 & 2 & 3 & 1 & 2 & 3 & 1 & 2 & 3 & 1 & 2 & 3 & 1 & 2 & 3 \\
\hline P1 & - & + & - & - & + & - & - & + & - & - & + & - & - & + & - & - & + & - \\
\hline P2 & - & + & - & - & + & - & - & + & - & - & + & - & - & + & - & - & + & - \\
\hline P3 & - & + & - & - & + & - & - & + & - & - & + & - & - & + & - & - & + & - \\
\hline
\end{tabular}

-- $=$ no negative phototropism $/+=$ was positive phototropism

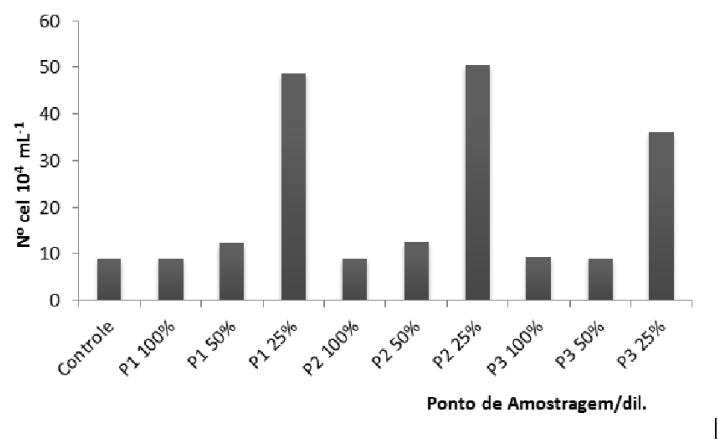

Figure 1 - Chronic toxicity assay with Selenastrum capricornutum.

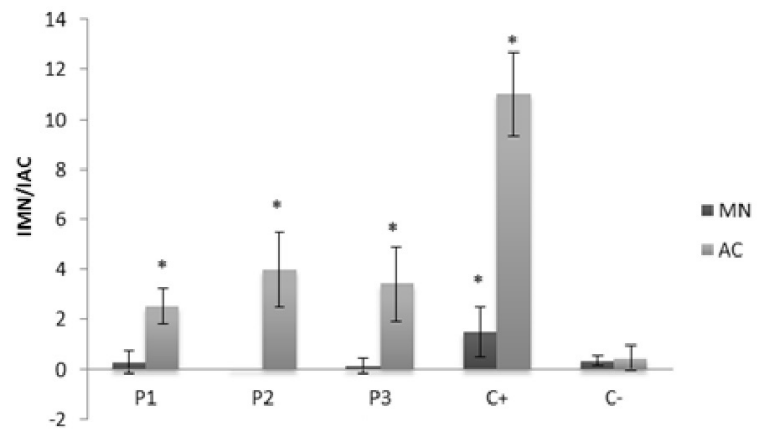

Figure 2 - Percentage of chromosomal aberrations (CA) and micronuclei (MN) in Allium cepa roots exposed to interstitial water.

only one study reporting contamination by intestinal parasites in vegetables sold in this region (Oliveira \& Germano, 1992), and until of the final writing of the present paper no studies could be found involving the application of ecotoxicological assays to the diagnosis or monitoring of vegetable irrigation waters.

Our results of bioassays with algae and flatworms showed only chronic toxicity in two of the three samples, represented

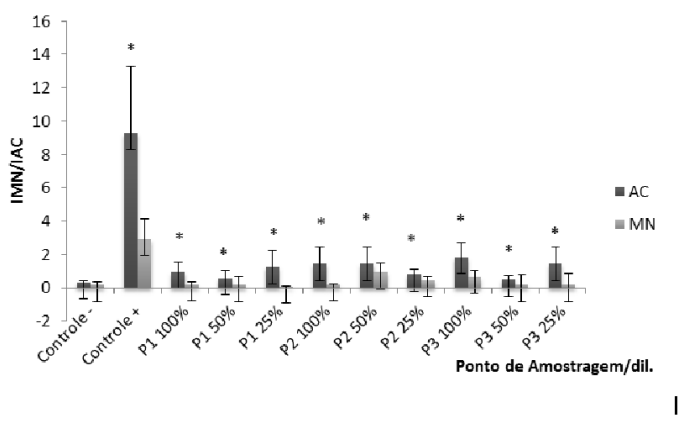

Figure 3 - Percentage of chromosomal aberrations (CA) and micronuclei $(\mathrm{MN})$ in Allium cepa roots exposed to irrigation water

${ }^{*} \mathrm{CA}$ values significantly higher than the negative control

by the lack of response of planarians to light. The absence of planarian mortality may indicate that the contaminants present in the samples were highly diluted or in non-lethal concentrations.

There was no algae toxicity, but, unlike, there was overgrowth of these organisms in the the sample diluted to $25 \%$, indicating a tendency to eutrophication. It is believed that, in this case, probably there was an adjustment in nutrient concentration so that at this dilution level it became adequate for algal reproduction (Von Sperling, 1996).

Such super-growth results after sample dilution may be attributed to the presence of nutrients from organic matter present in the water, possibly from domestic sewage, as attested by the results of physical-chemical and microbiological analyses, and/or more probably from leached fertilizers from the cultivated areas themselves which would stimulate the growth of algae. However, an excess of such fertilizers derived compounds may be harmful to water bodies, since they provide an eutrophic environment with these algae 
overgrowth. However, despite the results, we observed no visible signs of this phenomenon at the time of sampling.

Besides, low values of dissolved oxygen (DO), high conductivity values and color, (Table 1) allow us to infer the existence of a high load of organic pollution likely originated from domestic sewage in these waters also confirmed by analysis of thermotolerant coliforms (Table 2).Similar results to these were also found by Santos et al., (2009) and Bianchi et al. (2011).

In recent years, various studies testing the system Allium cepa has been conducted in order to evaluate the effects of industrial and domestic effluents into surface waters (Santos et al., 2009 ; Barbosa et al., 2010 ; Bianchi et al., 2011; Nunes et al., 2011; Düsman et al., 2013). Overall, the highest genotoxic activity values for superficial water samples were found in points 2 and 3, suggesting that these points had been compromised to a greater extent due to the presence of genotoxic compounds, a result that was also found in sediment samples. However, when analyzing the frequencies of $\mathrm{MN}$ in region $\mathrm{F} 1$ cells exposed to sediment samples, significantly higher values were found than those observed for the negative control in two of the three sampling points (P1 and P3), indicating that the sediment in these points had also a mutagenic activity. This activity found in the sediments could be explained by the fact that those, contrarily to surface water, accumulate pollutants, thus creating favorable conditions for regular measurement of the effects of certain impacts or changes the ecosystem may be subjected to (Kennish, 1998). The sediment's ability to accumulate compounds is what makes this compartment one of the most important to assess the contamination level of continental aquatic ecosystems. The environmental contamination indicator compounds found in the sediment may be organic, such as insecticides and herbicides, or inorganic, like trace elements. All these pollutants can form very stable compounds that are unlikely to be released into the water column and tend to build up in the sediment, where they can reach high concentrations higher even than the concentrations of common elements of the earth's crust (Esteves, 1998).

Positive results detected by analysis of some parameters in bioassays with higher plants indicate the presence of genotoxic and/or cytotoxic substances in the environment, thus demonstrating a direct or indirect potential risk to living beings that are in contact with it (Fiskesjö, 1994, Bianchi et al., 2011; Düsman et al., 2013).

Although no significant mutagenic activity has been found in the present study, the observed genotoxicity is still an important indicator of environmental pollution. By performing bioassays with plants that are sensitive to genotoxicity caused by industrial agents, which can serve as a first alert indicating the presence of environmental hazards in the water, air and soil (Ma, 1999; Barbosa et al., 2010). Moreover, such DNA changes, if not repaired by the cell system, can lead to mutations, the effects of which may range from cell inviability to the development of carcinogenic processes (Fernandes, 2005).

The causes of high AC frequencies and MNI (micronucleus index) found, respectively, in water and sediment samples in this study have not been investigated. It is known, however, that genotoxic activity is caused by the synergistic action of pollutants with varied chemical nature present in the environment, since environmental samples are a complex mix (Zagatto \& Bertoletti, 2006; Leme \& Marin-Morales, 2009).

The maximum value for fecal or thermotolerant coliforms under CONAMA Resolution No. 357: 2005 is 200 thermotolerant coliforms $100 \mathrm{~mL}^{-1}$ or $20 \mathrm{UFC} \mathrm{mL}^{-1}$ (BRAZIL, 2005). The WHO recommends that waters used for irrigation of crops that are eaten raw should have a maximum limit of 1000 fecal coliforms/100 mL per sample (WHO, 1989).

According to the guidelines set forth by the Brazilian legislation (more restrictive) and by the WHO (less restrictive), none of the samples fell within these limits, exceeding by far the acceptable limits for coliforms. Such results clearly allow us to assert the existence of contaminants of fecal origin from domestic sewage (Mazari-Hiriart et al., 2008; Camargo et al., 2009; Taban \& Halkman, 2011).

Taken together, the results lead to the conclusion that out of the three tested organisms, Allium cepa proved to be the most sensitive, allowing the identification of changes in cytogenetic levels even in trace concentrations of the toxic agent. The genotoxicity observed in sediment, where there is greater buildup of polluting substances, also implies a greater risk of contamination due to the possibility of migration and re-entry into the water column of toxic substances contained in the sediment in the presence of small environmental variations.

It was also determined that the basin's environmental integrity was compromised due to high loads of organic pollution, as shown by coliform analyses, with prevalence of microbiological contamination outside the levels recommended both by the Brazilian legislation and the WHO (Table 2). However, the observed anthropogenic contamination was not associated with significant toxicity in some of the tested organisms, like algae and planarians, which could possibly be explained by the absence of industrial discharges near these locations.

Finally, the present work represents a contribution to expand the limited data available in the literature about this important region of the Greater São Paulo and to better inform the public decision-making process with regard to the promotion of sustainable agriculture and the implementation of monitoring points at this location.

\section{ACKNOWLEDGMENTS}

We wish to thank the Chemistry and Environmental Sanitation Laboratory at FATEC-SP and the Ecotoxicology Laboratory at FATEC-SO for their assistance.

\section{REFERENCES}

BARBOSA, J. S., CABRAL, T. M., FERREIRA, D. N., AGNEZLIMA, L. F \& MEDEIROS, S.R. 2010. Genotoxicity assessment 
in aquatic environment impacted by the presence of heavy metals. Ecotox. Environ. Safety, 73: 320-325.

http://dx.doi.org/10.1016/j.ecoenv.2009.10.008

BIANCHI, J., ESPINDOLA, E. L. \& MARIN-MORALES, M. A. 2011. Genotoxicity and mutagenicity of water samples from the Monjolinho River (Brazil) after receiving untreated effluents. Ecotox. Environ. Safety, 74: 826 - 833.

http://dx.doi.org/10.1016/j.ecoenv.2010.11.006

BEST, J. B., MORITA, M. 1991. Toxicology of planarians. Hydrobiology, 227: 375-383. http://dx.doi.org/10.1007/978-94011-2775-2 53

BRAZIL - CONAMA (Conselho Nacional do Meio Ambiente). 2005. Resolução $\mathrm{n}^{\circ}$ 357, de 17 de Março de 2005. Brasília: Ministério do Meio Ambiente.

CALEVRO, F., FILIPPI, C., DERI, P., ALBERTOSI, C. \& BATISTONI, R. 1998. Toxic effects of Aluminum, Chromium and Cadmium in intact and regenerating freshwater planarians. Chemosphere, 37: 651-659.

CAMARGO, F. P., LEITE, M. A., SUZUKI, E. T., FRANCO, R. A. M \& HERNANDEZ, F. B. T. 2009. Parâmetros químicos e microbiológicos de dois córregos do Cinturão Verde de Ilha Solteira. In: 21st Scientific Initiation Congress at UNESP. São José do Rio Preto.

CETESB (Companhia Ambiental do Estado de São Paulo). 1991. Coliformes totais e fecais: detecção em amostras de água através do teste de presença-ausência: método de ensaio - Norma Técnica L5.240. São Paulo - SP. 17 p.

CHIOU, RJ. 2008. Risk assessment and loading capacity of reclaimed wastewater to be reused for agricultural irrigation. Environ. Monit. Assess., 142: 255-262. http://dx.doi.org/10.1007/s10661007-9922-9

DÜSMAN, E., LUZZA, M., SAVEGNAGO, L., LAUXEN, D. VICENTINI, V. E., TONIAL, I. B. \& SAUER, T. P. Allium cepa L. as a bioindicator to measure cytotoxicity of surface water of the Quatorze River, located in Francisco Beltrão, Paraná, Brazil. 2013. Environ. Monit. Assess (Print), Oct 27.

http://dx.doi.org/10.1007/s10661-013-3493-8

EL-SHAHABY, AO, ABDEL- MIGID, HM, SOLIMAN, MI \& Mashaly, IA. 2003. Genotoxicity Screening of Industrial Wastewater Using the Allium Cepa Chromosome Aberration Assay. Pakistan Journal of Biological Sciences, 6: 23-28.

http://dx.doi.org/10.3923/pjbs.2003.23.28.

ESTEVES, F. A. 1998. Fundamentos de limnologia. Interciência, Rio de Janeiro. 601p.

FACHINETTO, JM, BAGATINI, MD, DURIGON, J, SILVA, ACF \& TEDESCO S. B. 2007. Efeito anti-proliferativo das infusões de Achyrocline satureioides DC (Asteraceae) sobre o ciclo celular de Allium cepa. Rev Bras Farmacogn, 17: 49-54.

http://dx.doi.org/10.1590/S0102-695X2007000100011

FERNANDES, T. C. C. 2005. Investigação dos efeitos tóxicos, mutagênicos e genotóxicos do herbicida trifluralina, utilizando Allium cepa e Oreochromis niloticus como sistemas-testes. MSc. Dissertação. Universidade Estadual de São Paulo, Rio Claro. 212 p.

FISKESJO, G. 1994. The Allium Test II: Assessment of chemical's genotoxic potential by recording aberrations in chromosomes and cell divisions in root tips of Allium cepa L. Environmental Toxicology and Water Quality, 9: 234-241. http://dx.doi. org/10.1002/tox.2530090311

FRANCO, R. A. M, VANZELA, L. S. \& HERNANDEZ, F. B. T. 2006. Avaliação Biológica da qualidade da água para irrigação do Córrego Três Barras, Marinópolis, SP. In: 16th National Congress on Irrigation and Drainage, Goiânia - GO, Brazil.

GUECHEVA, T. N., ERDTMANN, B., BENFATO, M. S \& HENRIQUES, J. A. 2003. Stress protein response and catalase activity in freshwater planarian Dugesia (Girardia) schubarti exposed to copper. Ecotoxicology and Environmental Safety, 56: 351-357.

http://dx.doi.org/10.1016/S0147-6513(02)00065-9.

HELLAWELL, J. M. 1986. Biological Indicators of Freshwater Pollution and Environmental Management (Pollution Monitoring Series). Elsevier Applied Science Publishers, London and New York. 509 p.

http://dx.doi.org/10.1007/978-94-009-4315-5

KENNISH, J. M. 1998. Pollution impacts on marine biotic communities. CRC Press, Florida, USA. 310 p.

LEME, D. M, \& MARIN-MORALES, M. A. 2008. Chromosome aberration and Micronucleus frequencies in Allium cepa cells exposed to petroleum polluted water - A case study. Mutation Research, 650: 80-86.

http://dx.doi.org/10.1016/j.mrgentox.2007.10.006

LEME, D. M \& MARIN-MORALES, M. A. 2009. Allium cepa test in environmental monitoring: A review on its application. Mutation Research, 682: $71-81$.

http://dx.doi.org/10.1016/j.mrrev.2009.06.002

MA,T. H., XU, Z., XU,C., MCCONNELL, H., RABAGO, E. V., ARREOLA, G. A. \& ZHANG, H. 1995. The improved Allium/Vicia root tip micronucleus assay for clastogenicity of environmental pollutants. Mutation Research, 334(2): 185-195.

http://dx.doi.org/10.1016/0165-1161(95)90010-1

MA, T. H. 1999. The international program on plant bioassays and the report of the follow-up study after the hands-on workshop in China. Mutation Research, 426: 103-106. http://dx.doi. org/10.1016/S0027-5107(99)00049-4

MAROUELLI, W. A \& SILVA, H. R. 1998. Aspectos sanitários da água para fins de

irrigação. Technical Communication n ${ }^{\circ}$ 5. Embrapa, Brasília - DF. $7 \mathrm{p}$.

MATTOS, K. M. C. 2003. Viabilidade da Irrigação com Água Contaminada por Esgoto Doméstico na Produção Hortícola. Doctoral Thesis. Universidade Estadual de São Paulo, BotucatuSP. 146 p.

MAZARI-HIRIART, M., PONCE-DE-LEÓN, S., LÓPEZ-VIDAL, Y., ISLAS-MACÍAS, P. \& AMIEVA-FERNÁNDEZ, R.I. 2008. Microbiological Implications of Periurban Agriculture and Water Reuse in Mexico City. PLoS One 3(5): e2305.

DOI: 10.1371/journal.pone.0002305

NUNES, E. A., LEMOS, C. T., GAVRONSKI, L., MOREIRA, T.N., OLIVEIRA, N. C., \& SILVA, J. 2011. Genotoxic assessment on river water using different biological systems. Chemosphere, 84 (1) : 47-53

http://dx.doi.org/10.1016/j.chemosphere.2011.02.085

OLIVEIRA, C. A. F. \& GERMANO, P. M. L. 1992. Estudo da ocorrência de enteroparasitas em hortaliças comercializadas na região metropolitana de São Paulo - SP, Brasil. II - Pesquisa de protozoários intestinais. Revista Saúde Púbica, 26 (5): 332-335.

http://dx.doi.org/10.1590/S0034-89101992000500006

PALMA, P., ALVARENGA, P., PALMA,V., MATOS, C., FERNANDES, R. M., SOARES, A., \& BARBOSA, I. R. 2010. Evaluation of surface water quality using an ecotoxicological approach: a case study of the Alqueva Reservoir (Portugal). Environmental Science Pollution Research International, 17(3):703-716.

http://dx.doi.org/10.1007/s11356-009-0143-3

PAPADOPOULOS, F., PARISSOPOULOS, G., PAPADOPOULOS, A., ZDRAGAS, A., NTANOS, D., PROCHASKA, C. \& METAXA, I. 2009. Assessment of reclaimed municipal wastewater application on rice cultivation. Environmental Management, 43:135-143. http://dx.doi.org/10.1007/s00267008-9221-4 
RADIX, P., LEONARD, M., PAPANTONIOU, C., ROMAN, G., SADUTER, E., GALLOTTI - SCHMIH, S., THIÉBAUD, H. \& VASSEUR, P. 2000. Comparison of four chronic toxicity test using Algae, Bacteria and Invertebrates assessed with sixteen chemicals. Ecotoxicology and Environmental Safety, 47: 186194.

http://dx.doi.org/10.1006/eesa.2000.1966

RUBINGER, C. F. 2009. Seleção de métodos biológicos para avaliação toxicológica de efluentes industriais. Dissertação. Universidade Federal de Minas Gerais, Belo Horizonte-MG. $71 \mathrm{p}$.

SANTOS, TC, MACIEL, LF, LEAL, KS, BENDER, AE, PAIVA, TS, GARCIAS, GL \& Martino-Roth, MG. 2009. Mutagenic potential of water from Pelotas

Creek in Rio Grande do Sul, Brazil. Genet. Mol. Res., 8 (3): 10571066.

http://dx.doi.org/10.4238/vol8-3gmr622

SICKO-GOAD, L. \& STOERMER, E. F. 1988. Effects of toxicants on phytoplankton with special reference to the Laurentian Great Lakes. In: EVANS, MS. (Ed.). Toxic contaminants and ecosystem health - A great lakes focus. Advances in environmental science and technology, 21: 19-51.

VON SPERLING, M. 1996. Introdução à qualidade das águas e ao tratamento de esgotos. $2^{\text {a }}$ ed. Escola de Engenharia da UFMG, Belo Horizonte. 243 p.
TABAN, B. M \& HALKMAN, K. A. 2011. Do leafy green vegetables and their ready-to eat [RTE] salads carry a risk of foodborne pathogens? Anaerobe 17: 286-287. http://dx.doi.org/10.1016/j. anaerobe.2011.04.004

TEIXEIRA, R. O, CAMPAROTO, M. L, MANTOVANI, M. S. \& VICENTINI, V. E. P. 2003. Assessment of two medicinal plants, Psidium guajava $L$ and Achillea millefolium $L$, in vivo assays. Gen. Mol. Biol., 26: 551-555.

USEPA (United States Environmental Protection Agency). 2002. Short-term methods for estimating the chronic toxicity of effluents and receiving waters to fresh water organism. 4th ed. Washington, DC. 335p.

WHO (World Health Organization). 1989. Health guidelines for use of wastewater in agriculture and acquaculture. Technical Report Series $\mathrm{n}^{\circ} 778$. Geneva. $76 \mathrm{p}$.

YOSHIHARA, S., \& MURUGANANTHAN, M. 2009. Decomposition of various endocrine-disrupting chemicals at boron-doped diamond electrode. Electrochimica Acta, 54: 20312038.

http://dx.doi.org/10.1016/j.electacta.2008.07.006.

ZAGATTO, P. A. \& BERTOLETTI, E. 2006. Ecotoxicologia Aquática - Princípios e Aplicações. Editora Rima, São Carlos - SP. 464 p. 